\title{
Increased expression of CCAAT/enhancer binding protein- $\beta$ and $-\delta$ and monocyte chemoattractant protein-1 genes in aortas from hyperinsulinaemic rats
}

\author{
Y. Sato $\cdot$ Y. Nishio $\cdot$ O. Sekine $\cdot$ K. Kodama $\cdot$ Y. Nagai $\cdot$ \\ T. Nakamura $\cdot$ H. Maegawa $\cdot$ A. Kashiwagi
}

Received: 27 April 2006 / Accepted: 8 August 2006 / Published online: 16 December 2006

(C) Springer-Verlag 2006

\begin{abstract}
Aims/hypothesis We evaluated whether hyperinsulinaemia stimulates the expression of transcription factor CCAAT/ enhancer binding protein (C/EBP)- $\beta$ and $\mathrm{C} / \mathrm{EBP}-\delta$ and leads to the induction of the chemokine (C-C motif) ligand 2 gene ( $\mathrm{Ccl} 2$, also known as $M C P-1)$ expression in aortas. Methods Hyperinsulinaemia was induced by feeding rats a high-fructose diet. CCL2 production was analysed by ELISA. The expression of Ccl2, Cebpb and Cebpd mRNAs was investigated by quantitative RT-PCR. The binding of $\mathrm{C} / \mathrm{EBP}-\beta$ to $\mathrm{Ccl} 2$ was assessed by chromatin immunoprecipitation (ChIP) assay.

Results Insulin at a concentration of $10 \mathrm{nmol} / 1$ significantly stimulated the expression of Cebpb,Cebpd and Ccl2 mRNAs, depending on activation of phosphatidylinositol 3-kinase (PI3K) in cultured vascular smooth muscle cells. The knockdown of C/EBP- $\beta$ with siRNA abolished the insulin-induced Ccl 2 mRNA expression. In the aortas from fructose-fed rats, the levels of phosphorylation of Akt/protein kinase B, a downstream effector of PI3K, were also increased. The expression of $C e b p b, C e b p d$ and $C c l 2$ mRNAs in the aortas
\end{abstract}

Electronic supplementary material Supplementary material is available in the online version of this article at http://dx.doi.org/ $10.1007 / \mathrm{s} 00125-006-0480-4$ and is accessible to authorised users.

Y. Sato $\cdot$ Y. Nishio $(\bowtie) \cdot$ O. Sekine $\cdot$ K. Kodama $\cdot$ Y. Nagai $\cdot$

H. Maegawa $\cdot$ A. Kashiwagi

Division of Endocrinology and Metabolism,

Department of Medicine, Shiga University of Medical Science,

Seta-Tsukinowa-Cho,

Otsu, Shiga 520-2192, Japan

e-mail: nishio@belle.shiga-med.ac.jp

T. Nakamura

The Department of Anatomy,

Shiga University of Medical Science,

Seta, Otsu, Shiga 520-2192, Japan from fructose-fed rats were significantly elevated, by 330 , 300 and $300 \%$, respectively, compared with those of controlfed rats. The induction $C c l 2$ mRNA expression in the aortas was significantly correlated with the expression of Cebpb and Cebpd mRNAs in the aortas. Furthermore, the ChIP assay showed elevated binding of C/EBP- $\beta$ to the $5^{\prime}$ upstream region of $C c l 2$ in the aortas from fructose-fed rats. Conclusions/interpretation These findings clearly indicate the role of C/EBPs in the mechanism of upregulation of CCL2, an inflammation-related protein, observed in the hyperinsulinaemic state, which may initiate the process of atherosclerosis.

Keywords Atherosclerosis - C/EBP - ChIP - Inflammation . Hyperinsulinaemia $\cdot$ CCL2 $\cdot$ PI3K $\cdot$ MCP-1
Abbreviations
$\mathrm{C} / \mathrm{EBP} \quad \mathrm{CCAAT} / \mathrm{enhancer}$ binding protein
ChIP chromatin immunoprecipitation
CRP C-reactive protein
CCL2 chemokine (C-C motif) ligand 2 (also known as monocyte chemoattractant protein-1)
NF-кB nuclear factor-kappa B
PI3K phosphatidylinositol 3-kinase
VSMC vascular smooth muscle cell

\section{Introduction}

Atherosclerosis is the result of excessive proliferative and inflammatory responses of vascular tissues, including migration and proliferation of smooth muscle cells and infiltration of inflammatory cells [1]. In the atherosclerotic lesion, vascular cells release a number of inflammatory 
cytokines, such as IL-6, IL-1, TNF- $\alpha$ and chemokine (C-C motif) ligand 2 (CCL2, also known as monocyte chemoattractant protein-1) [2]. The role of insulin in atherogenesis has long been a matter of debate, with many epidemiological studies [3] suggesting that hyperinsulinaemia is a strong independent risk factor for a cardiovascular event $[4,5]$. Several clinical studies, including the UKPDS [6], have shown that insulin treatment does not increase the risk of cardiovascular disease, therefore, it may be that a decrease in insulin action in the vascular tissue is responsible for increased cardiovascular risk in the hyperinsulinaemic state. We recently reported that in the presence of physiological concentrations of insulin and continuous activation of membrane-targeted phosphatidylinositol 3-kinase (PI3K) through the overexpression of p110CAAX, Ccl2 expression is increased through the activation of transcription factors known as CCAAT/enhancer binding proteins (C/EBPs) [7]. In addition to CCL2, C/EBPs are responsible for the induction of a wide array of other genes, including those encoding proteins with a role in innate immunity, cell proliferation, adipogenesis, inflammatory response and the acute-phase response, such as IL-6, IL-8, IL-12, TNF- $\alpha$ and C-reactive protein (CRP) [8-10]. Several reports have shown that $\mathrm{C} / \mathrm{EBPs}$ play an important role in atherosclerosis [11-13]. Thus, it might be possible that insulin induces the expression of genes involved in inflammation through activation of the C/EBPs in the cardiovascular tissues. While several lines of epidemiological evidence indicate that hyperinsulinaemia is associated with increased levels of inflammatory proteins such as serum CRP [14, 15], to our knowledge, there are no data on the expression of $\mathrm{C} / \mathrm{EBP}$ genes or the role of C/EBPs in the expression of genes encoding inflammatory cytokines in cardiovascular tissues in the hyperinsulinaemic state. Use of a hyperinsulinaemic rat model to elucidate the role of C/EBPs in the gene expression of inflammatory cytokines in the cardiovascular tissues may provide insights into cardiovascular abnormalities in hyperinsulinaemic insulin-resistant patients and possible molecular targets for therapeutic amelioration of the development of atherosclerosis in these patients.

The aim of this study was to investigate the expression of Cebpb, Cebpd and Ccl2 in cardiovascular tissues from fructose-feeding-induced hyperinsulinaemic rats and in cultured vascular smooth muscle cells (VSMCs) exposed to physiological concentrations of insulin.

\section{Materials and methods}

\section{Materials}

Human recombinant insulin was kindly provided by Eli Lilly \& Co. (Indianapolis, IN, USA). DMEM and FCS were from
Invitrogen (Grand Island, NY, USA). Akt/protein kinase B and phospho-Akt antibodies were from Cell Signaling Technology (Beverly, MA, USA). Antibodies to C/EBP- $\beta$ and C/EBP- $\delta$ were from Santa Cruz Biotechnology (Santa Cruz, CA, USA). Antibody to CCL2 was from Chemicon (Temecula, CA, USA). LY294002 was purchased from Sigma (St Louis, MO, USA). XAR-5 film was purchased from Eastman Kodak (Rochester, NY, USA).

\section{Cell culture}

VSMCs were isolated from the aortas of male SpragueDawley rats (200-300 g) by enzymatic digestion, and maintained in DMEM supplemented with $10 \%$ FCS, $80 \mathrm{U} / \mathrm{ml}$ penicillin $\mathrm{G}$ and $80 \mu \mathrm{g} / \mathrm{ml}$ streptomycin in $100-$ $\mathrm{mm}$ plates $\left(5 \times 10^{6}\right.$ cells per dish), as described previously [16]. VSMCs were used between the 6th and 12th passages. Cell growth was arrested for $48 \mathrm{~h}$ in DMEM supplemented with $0.1 \%$ FCS before the experiments.

\section{Cell treatment}

siRNA analysis To silence C/EBP- $\beta$, siRNA against rat Cebpb mRNA was utilised (SMART pool Reagent; Dharmacon, Lafayette, CO, USA). A control siRNA was also utilised (non-silencing control siRNA; Qiagen, Valencia, CA, USA). Rat VSMCs were transfected with $10 \mathrm{nmol} / 1$ siRNA using DharmaFECT 1 (Dharmacon), and the silencing effect was confirmed by real-time PCR and western blotting $48 \mathrm{~h}$ after transfection. VSMCs transfected with siRNA were starved for $48 \mathrm{~h}$ and then stimulated by the addition of $10 \mathrm{nmol} / 1$ insulin for $4 \mathrm{~h}$ at $37^{\circ} \mathrm{C}$.

\section{Animals}

Six-week-old male Sprague-Dawley rats (Japan SLC, Shizuoka, Japan) were housed in an environmentally controlled room with a $12 \mathrm{~h}$ light-dark cycle. The animals were divided into a control diet group and a high-fructose diet group. The rats in each group were fed for 4 weeks. The control diet (Oriental Yeast, Tokyo, Japan) consisted of $58 \%$ carbohydrate (no fructose), $12 \%$ fat and $30 \%$ protein (energy \% of diet). The diet high in fructose (Oriental Yeast) contained $67 \%$ carbohydrate $(98 \%$ of which was fructose), $13 \%$ fat and $20 \%$ protein. The rats were pair-fed. The day before the experiment, food was withdrawn from the cages of all animals at 20.00 hours. Rats were re-fed in the dark from 06.00-08:00 hours, at which time the chow was removed. After $2 \mathrm{~h}$ of food deprivation, rats were anaesthetised, and the aorta and the heart were removed and immediately frozen in liquid nitrogen and stored at $-80^{\circ} \mathrm{C}$ until use. All experiments were approved by the Shiga University of Medical Science Animal Care Committee. 
Western blot analysis

The aortas from experimental animals were powdered in liquid nitrogen and lysed in a solubilising buffer containing $20 \mathrm{mmol} / \mathrm{l} \mathrm{Tris}-\mathrm{HCl}, \mathrm{pH} 7.5,1 \mathrm{mmol} / \mathrm{l}$ EDTA, $140 \mathrm{mmol} / 1$ $\mathrm{NaCl}, 1 \%$ Nonidet P-40 (Nakarai Tesque, Kyoto, Japan), $50 \mathrm{U} / \mathrm{ml}$ aprotinin and $1 \mathrm{mmol} / 1$ phenylmethylsulfonyl fluoride (PMSF) for $10 \mathrm{~min}$ at $4^{\circ} \mathrm{C}$. For western blot analysis, whole-tissue lysates were denatured by boiling in Laemmli sample buffer containing $100 \mathrm{mmol} / \mathrm{l}$ dithiothreitol, resolved by SDS-PAGE, and then transferred to nitrocellulose by electroblotting. Blots were then incubated with a rabbit antiphospho-Akt primary antibody, a rabbit anti-Akt primary antibody, a rabbit anti-CCL2 primary antibody, a rabbit anti$\mathrm{C} / \mathrm{EBP}-\beta$ primary antibody or a rabbit anti-C/EBP- $\delta$ primary antibody plus a horseradish peroxidase-linked secondary antibody (GE Healthcare Bio-Sciences, Piscataway, NJ, USA), followed by chemiluminescence detection, according to the instructions of the manufacturer (PerkinElmer Life Sciences, Boston, MA, USA).

Chromatin immunoprecipitation assay

The chromatin immunoprecipitation (ChIP) assay protocol was adapted from methods described elsewhere $[17,18]$. In brief, rat VSMCs $\left(1 \times 10^{8}\right.$ cells/condition) were cross-linked with $1 \%$ formaldehyde in PBS at $37^{\circ} \mathrm{C}$ for $15 \mathrm{~min}$. Cells were harvested with cell scraping buffer $(1 \mathrm{ml} /$ plate of icecold PBS with the protease and phosphatase inhibitors $1 \mathrm{mmol} / 1 \mathrm{PMSF}$, protease inhibitor cocktail [Roche Diagnostics, Tokyo, Japan]). Cells were then pelleted, resuspended in SDS lysis buffer (1\% SDS, $10 \mathrm{mmol} / 1$ EDTA, $50 \mathrm{mmol} / \mathrm{l}$ Tris- $\mathrm{HCl}, \mathrm{pH} 8$, with protease and phosphatase inhibitors), and incubated on ice for $10 \mathrm{~min}$. To shear chromatin, the lysate was sonicated on ice, yielding chromatin fragments of around $600 \mathrm{bp}$ in size. Samples were centrifuged at $17,000 \mathrm{~g}$ for $10 \mathrm{~min}$ at $4^{\circ} \mathrm{C}$ and the supernatant fraction was divided into aliquots for subsequent tenfold dilution in ChIP dilution buffer $(0.01 \%$ SDS, $1.1 \%$ Triton X-100, $1.2 \mathrm{mmol} / 1$ EDTA, $16.7 \mathrm{mmol} / 1$ Tris$\mathrm{HCl}, \mathrm{pH} 8$, with protease and phosphatase inhibitors). To provide the same amount of DNA for each sample, DNA concentration was measured using Hoechst 33258 dye (Invitrogen, Carlsbad, CA, USA). To reduce non-specific binding, each 1-ml chromatin sample was precleared with $30 \mu \mathrm{l}$ of protein A-agarose slurry (Upstate, Charlottesville, VA, USA), supplemented with $400 \mu \mathrm{g} / \mathrm{ml}$ sonicated $E$. coli DNA (Invitrogen, Carlsbad, CA, USA), for $1 \mathrm{~h}$ at $4^{\circ} \mathrm{C}$. Chromatin complexes were immunoprecipitated for 12 $18 \mathrm{~h}$ at $4^{\circ} \mathrm{C}$ with $1-2 \mu \mathrm{g}$ of primary antibody or nonspecific antibody (control) to provide negative controls. Immune complexes were collected with $30 \mu \mathrm{l}$ of protein Aagarose for $3 \mathrm{~h}$ at $4^{\circ} \mathrm{C}$, followed by centrifugation at
$17,000 \mathrm{~g}$ for $1 \mathrm{~min}$ at $4^{\circ} \mathrm{C}$. The precipitates were washed with $1 \mathrm{ml}$ of each of the following buffers twice in succession for $5 \mathrm{~min}$ at $4^{\circ} \mathrm{C}$ : low-salt wash buffer $(0.1 \%$ SDS, $1 \%$ Triton X-100, $2 \mathrm{mmol} / 1$ EDTA, $20 \mathrm{mmol} / 1$ Tris$\mathrm{HCl}, \mathrm{pH} 8.0,150 \mathrm{mmol} / 1 \mathrm{NaCl})$, high-salt wash buffer $(0.1 \%$ SDS, $1 \%$ Triton X-100, $2 \mathrm{mmol} / 1$ EDTA, $20 \mathrm{mmol} / 1$ Tris$\mathrm{HCl}, \mathrm{pH} 8.0,500 \mathrm{mmol} / \mathrm{l} \mathrm{NaCl}$ ), $\mathrm{LiCl}$ wash buffer (250 mmol/1 LiCl, 1\% Nonidet P-40, 1\% sodium deoxycholate, $1 \mathrm{mmol} / \mathrm{l}$ EDTA, $10 \mathrm{mmol} / \mathrm{l}$ Tris- $\mathrm{HCl}$, $\mathrm{pH} 8.0$ ), and TE buffer (10 mmol/1 Tris-HCl, pH 8.0, 1 mmol/1 EDTA). Chromatin complexes were eluted with $200 \mu \mathrm{l}$ of elution buffer ( $1 \% \mathrm{SDS}, 0.1 \mathrm{~mol} / 1 \mathrm{NaHCO}_{3}, 10 \mathrm{mmol} / \mathrm{l}$ dithiothreitol) at $65^{\circ} \mathrm{C}$. To reverse cross-linking, $\mathrm{NaCl}(200 \mathrm{mmol} / \mathrm{l}$ final concentration) was added, and the samples were incubated at $65^{\circ} \mathrm{C}$ for over $6 \mathrm{~h}$. To digest proteins, samples were incubated with $10 \mathrm{mmol} / \mathrm{l}$ EDTA, $40 \mathrm{mmol} / \mathrm{l}$ Tris-HCl, $\mathrm{pH}$ 6.5 , and $50 \mu \mathrm{g} / \mathrm{ml}$ proteinase $\mathrm{K}$ at $45^{\circ} \mathrm{C}$ for $90 \mathrm{~min}$. Samples were extracted with phenol-chloroform, resuspended in $20 \mu \mathrm{l}$ of TE buffer, and stored at $-80^{\circ} \mathrm{C}$ until quantitative real-time PCR analysis was performed.

For the ChIP assay using tissue samples, the aortas were incubated with $1 \%$ formaldehyde in PBS at room temperature for $15 \mathrm{~min}$, followed by incubation with PBS supplemented with $125 \mathrm{mmol} / \mathrm{l}$ glycine for $5 \mathrm{~min}$. Samples were then frozen in liquid nitrogen and stored at $-80^{\circ} \mathrm{C}$ until use. Frozen tissues were powdered in liquid nitrogen, and $2 \mathrm{ml}$ ice-cold PBS was added. After homogenisation, samples were resuspended in $500 \mu \mathrm{l}$ cell lysis buffer (5 mmol/1 1,4-piperazinediethanesulfonic acid [PIPES], $85 \mathrm{mmol} / 1 \mathrm{KCl}, 0.5 \%$ Nonidet P-40) with phosphatase inhibitors, the protease inhibitor cocktail and PMSF $(1 \mathrm{mmol} / \mathrm{l})$, and incubated on ice for $15 \mathrm{~min}$. They were then centrifuged at $17,000 \mathrm{~g}$ for $1 \mathrm{~min}$ at $4^{\circ} \mathrm{C}$. The pellet was resuspended in $300 \mu \mathrm{l}$ SDS lysis buffer with the same protease inhibitors and incubated on ice for $10 \mathrm{~min}$. Approximately $0.1 \mathrm{~g}$ of glass beads (G-1277; Sigma) was added to each sample. The mixture of nuclei and glass beads was sonicated on ice until the average length of chromatin was about $600 \mathrm{bp}$, and then microfuged at $17,000 \mathrm{~g}$ for $10 \mathrm{~min}$ at $4^{\circ} \mathrm{C}$ to remove debris.

RNA extraction and real-time PCR analysis

Frozen tissues were powdered in liquid nitrogen, and total RNA was extracted using Trizol reagent (Invitrogen, Carlsbad, CA, USA). Reverse transcription was performed using $1 \mu \mathrm{g}$ of total RNA and reverse transcriptase (Invitrogen, Carlsbad, CA, USA). Real-time quantitative PCR was performed using the fluorescent dye SYBR Green I (Roche Molecular Biochemicals, Mannheim, Germany) and real-time PCR system (Roche). To exclude the contamination of non-specific PCR products, melting curve analysis was applied to all final PCR products after the 
cycling protocol. Finally, the quality of the PCR products was analysed by conventional agarose gel electrophoresis. All the quantitative data were normalised by the intensity of 18s rRNA signals.

Immunohistochemical analysis

Immunohistochemical analysis was performed as described previously $[19,20]$. Briefly, rats were perfused with a fixative containing $4 \%$ paraformaldehyde, $0.5 \%$ glutaraldehyde and $0.2 \%$ picric acid in $0.1 \mathrm{~mol} / 1$ phosphate buffer. The aortic tissue was dissected out and immersed for $24 \mathrm{~h}$ in a postfixative containing $4 \%$ paraformaldehyde, $0.2 \%$ picric acid in $0.1 \mathrm{~mol} / \mathrm{l}$ phosphate buffer at $4^{\circ} \mathrm{C}$. The sections were incubated for 2 days with antibody against CCL2, or C/EBP- $\beta$ and $\alpha$-smooth muscle actin ( $\alpha$-SMA), diluted in accordance with the manufacturer's instructions. The sections were then incubated with the species-specific secondary antibodies conjugated to either fluorescein isothiocyanate (FITC) or Texas Red and viewed using fluorescence microscopy (Olympus IX70, Japan). Images were taken with a CCD camera (Cool SNAP/HQ; Nippon Roper, Osaka, Japan).

Northern blot analysis

Total RNA $(30 \mu \mathrm{g})$ was denatured and electrophoresed on a $1 \%$ agarose gel and blotted onto a Nytran $\mathrm{N}$ membrane. The membrane was incubated with specific probes, washed, and visualised by autoradiography. All the quantitative data were corrected by the intensity of glyceraldehyde-3phosphate dehydrogenase (Gapdh) mRNA signals.

Primer design

The sets of PCR primers were designed as shown in Electronic supplementary material (ESM) Table 1.

\section{CCL2 ELISA}

Concentrations of CCL2 in plasma and conditioning media were determined using an ELISA kit (BioSource International, Camarillo, CA, USA).

\section{Statistical analysis}

Values are expressed as means \pm SEM. The Tukey-Kramer comparison test was used to determine the significance of differences between four or more groups. The non-paired $t$ test was used to determine the significance of differences between two groups. Pearson correlations and scatter plots were used to evaluate bivariate relationships. A $p$ value of less than 0.05 was considered significant.

\section{Results}

Insulin induces $C c l 2$ gene expression and secretion of the protein through the PI3K pathway in VSMCs

Insulin at $10 \mathrm{nmol} / 1$ significantly $(p<0.01)$ increased $C c l 2$ mRNA by 2.2 -fold as compared with levels in the absence of insulin (Fig. 1a). The effect of insulin on $\mathrm{Ccl} 2$ gene expression was significantly $(p<0.01)$ inhibited in the presence of $50 \mu \mathrm{mol} / 1 \mathrm{LY} 294002$, a PI3K inhibitor, indicating the involvement of the PI $3 \mathrm{~K}$ pathway in the induction of $\mathrm{Ccl} 2$ gene expression by insulin (Fig. 1a). To investigate whether CCL2 production is induced by

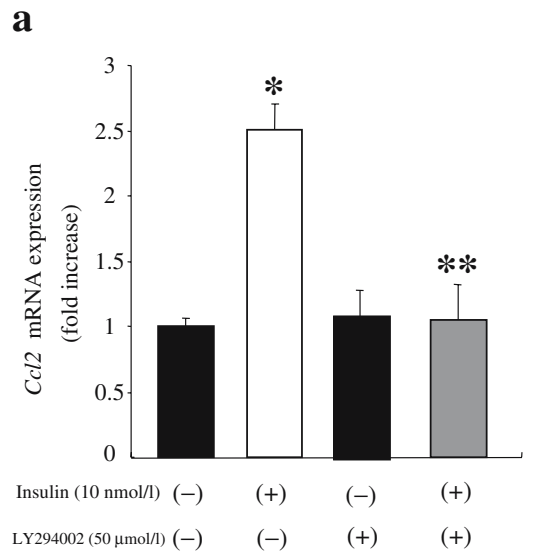

b

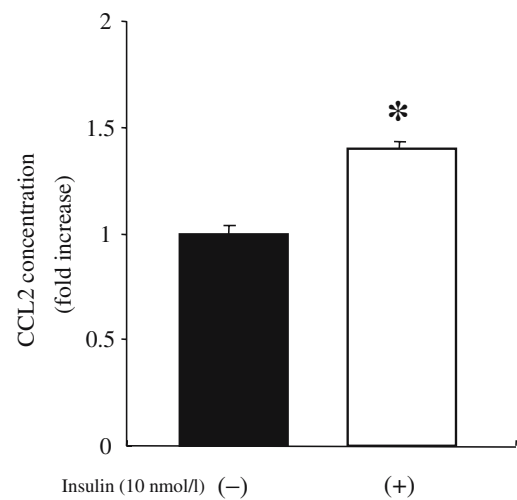

Fig. 1 Insulin induces $\mathrm{Ccl} 2$ gene expression and CCL2 protein secretion through the PI3K pathway in VSMCs. a VSMCs were starved for $48 \mathrm{~h}$ and incubated with or without LY294002 for $30 \mathrm{~min}$. The cells were stimulated with or without $10 \mathrm{nmol} / 1$ insulin for $4 \mathrm{~h}$. $\mathrm{Ccl} 2$ gene expression was examined by real time RT-PCR analysis. Results are expressed as mean \pm SEM of four experiments. b CCL2 concentrations in conditioned medium. VSMCs were starved for $48 \mathrm{~h}$ and stimulated with $(n=4)$ or without $(n=4) 10 \mathrm{nmol} / \mathrm{l}$ insulin for $24 \mathrm{~h}$. The value was normalised to the DNA content of the dishes. The mean value of CCL2 production of control cells was $7.75 \pm 1.31 \mathrm{pg} \cdot \mu \mathrm{g}$ $\mathrm{DNA}^{-1} \cdot 24 \mathrm{~h}^{-1}$. Values are the means $\pm \mathrm{SEM}$ of four experiments. ${ }^{*} p<0.01$ vs control; ${ }^{* *} p<0.01$ vs insulin without LY294002 
insulin, rat VSMCs were incubated with or without insulin for $24 \mathrm{~h}$. In the presence of $10 \mathrm{nmol} / \mathrm{l}$ insulin, CCL2 secretion in the media was significantly $(p<0.01)$ increased by 1.4-fold, compared with that in the absence of insulin (Fig. 1b).

Insulin induces the expression of Cebpb and Cebpd and increases the binding of $\mathrm{C} / \mathrm{EBP}-\beta$ to the $\mathrm{Ccl} 2$ promoter in VSMCs

Insulin at $10 \mathrm{nmol} / 1$ significantly $(p<0.01)$ increased Cebpb and Cebpd mRNA levels by 1.4-fold and 1.6-fold, respectively, compared with levels in the absence of stimulation (Fig. 2a,b). The effect of insulin on Cebpb and Cebpd expression was significantly $(p<0.01)$ inhibited by the addition of $50 \mu \mathrm{mol} / 1 \mathrm{LY} 294002$, indicating the involvement of the PI3K pathway in the induction of Cebpb and Cebpd expression by insulin (Fig. 2a,b). As reported previously [7], two binding sites for $\mathrm{C} / \mathrm{EBP}$, located in the $5^{\prime}$ upstream region of $\mathrm{Ccl} 2$ play a crucial role in the $\mathrm{PI} 3 \mathrm{~K}$-dependent regulation of this gene. Based on this we investigated the effects of insulin on expression of Cebpb and Cebpd and the binding of the protein products to these sites. $\mathrm{C} / \mathrm{EBP}-\beta$ binding to the $5^{\prime}$ upstream region of the $\mathrm{Ccl} 2$ gene was examined with the ChIP assay. Primers were designed for detecting the site of $\mathrm{C} / \mathrm{EBP}$ binding at $-3223 \mathrm{bp}$ from the starting point of transcription (Fig. 2c). The ChIP assay clearly showed that in the cells treated with $10 \mathrm{nmol} / 1$ insulin, $\mathrm{C} / \mathrm{EBP}-\beta$ binding to the $5^{\prime}$ upstream region of the $\mathrm{Ccl} 2$ gene was increased by three-fold $(p<0.01)$ compared with that in the untreated cells (Fig. 2d,e).

To confirm the role of C/EBPs in the expression of the Ccl2 gene, siRNA duplexes against $C e b p b$ mRNA, were transfected into rat VSMCs, followed by insulin stimulation. The siRNA duplexes directed against Cebpb mRNA, suppress both mRNA (Fig. 3a) and protein (Fig. 3b) production. Silencing of $\mathrm{C} / \mathrm{EBP}-\beta$, completely blocked the expression of $\mathrm{Ccl} 2$ induced by insulin (Fig. 3c).

\section{Characteristics of experimental animals}

To examine the effects of insulin on Cebpb, Cebpd and $\mathrm{Ccl} 2$ expression in cardiovascular tissues, we studied rats fed on a fructose diet, which show insulin resistance and hyperinsulinaemia [21, 22]. As shown in Table 1 , the body weight gains of the rats fed on the control diet and the rats fed on the fructose diet were similar over the study period. There was no difference in blood glucose levels between the groups, but the fructose-fed rats showed higher levels of plasma insulin $(100 \%$ increase, $p<0.01)$, total cholesterol
Fig. 2 Insulin induces $C e b p b$ and Cebpd expression and increases the binding of $\mathrm{C} / \mathrm{EBP}$ $\beta$ to the $\mathrm{Ccl} 2$ gene promoter in VSMCs. a, b VSMCs were starved for $48 \mathrm{~h}$ and incubated with or without LY294002 for $30 \mathrm{~min}$. The cells were stimulated with or without 10 $\mathrm{nmol} / 1$ insulin for $4 \mathrm{~h}$. The expression of Cebpb and Cebpd was examined by real time RTPCR analysis. c Schematic structure of $5^{\prime}$ upstream region of the rat $C c l 2$ gene. d, e Quiescent VSMCs were treated with or without $10 \mathrm{nmol} / \mathrm{l}$ insulin for $1.5 \mathrm{~h}$. The amount of input DNA was quantified with Hoechst 33258 dye and the quality was analysed with realtime PCR. Insulin increased the binding of $\mathrm{C} / \mathrm{EBP}-\beta$ to the $C c l 2$ gene promoter as quantified by ChIP assay with real-time PCR analysis in VSMCs. Values are the means \pm SEM of four experiments. ${ }^{*} p<0.01$ vs control; $* * p<0.01$ vs insulin without LY294002. IP, immunoprecipitation; $A b$, antibody

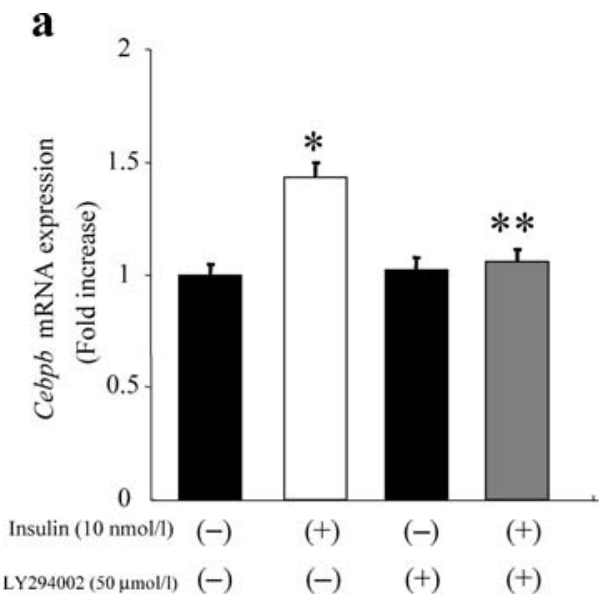

c

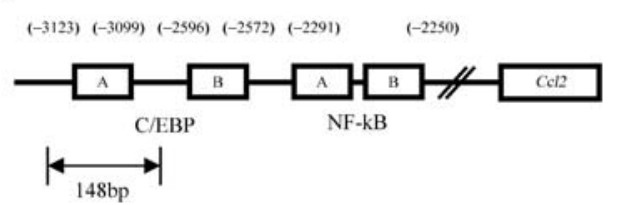

d

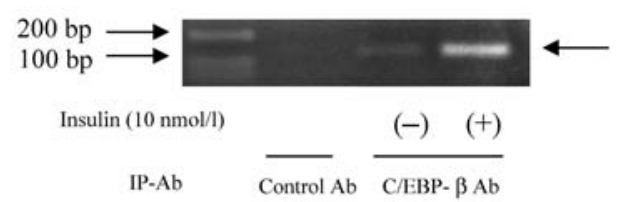

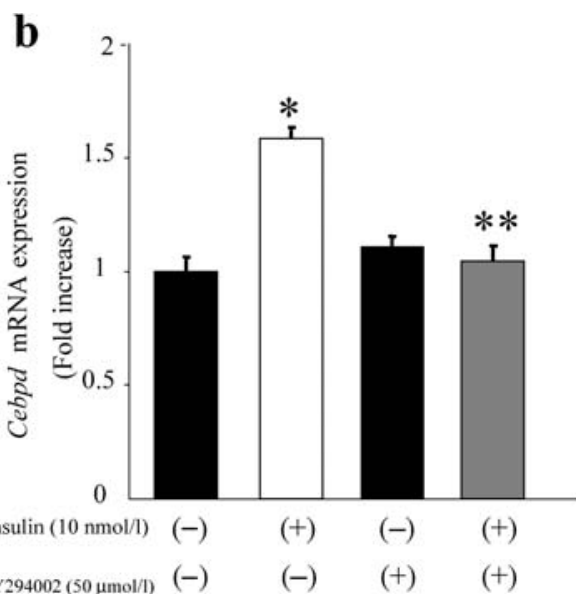

e

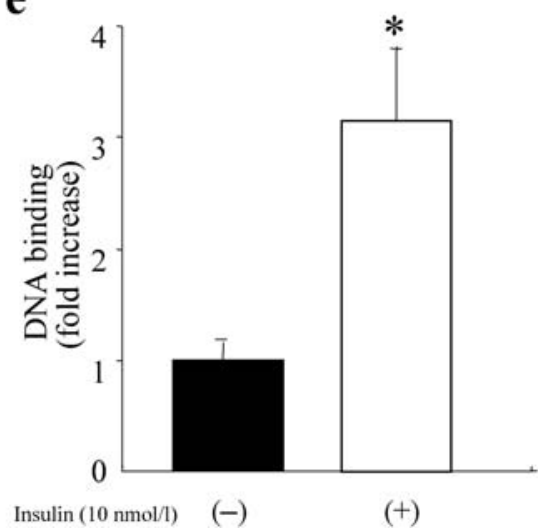


a

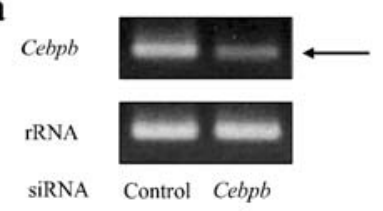

b

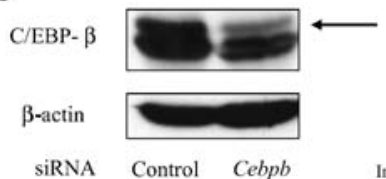

siRNA Control Cebpb

Fig. 3 Silencing of $\mathrm{C} / \mathrm{EBP}-\beta$ completely blocks insulin-induced $C c l 2$ mRNA expression. siRNA duplexes directed against Cebpb mRNA were transfected into rat VSMCs. Transfected cells were starved for $48 \mathrm{~h}$ and then stimulated with $10 \mathrm{nmol} / 1$ insulin for $4 \mathrm{~h}$. The siRNA duplexes against $C e b p b$ mRNA suppress $C e b p b$ mRNA expression (a) and C/EBP- $\beta$ production (b). Silencing of C/EBP- $\beta$, completely blocked the expression of $C c l 2$ induced by insulin (c). Values are the means \pm SEM of four experiments. ${ }^{*} p<0.01$ vs control without insulin stimulation; ${ }^{* *} p<0.01$ vs control siRNA with insulin stimulation

(27\% increase, $p<0.05)$, and triacylglycerol $(174 \%$ increase, $p<0.01)$. They showed slightly higher plasma CCL2 levels, but the difference was not significant.

Phosphorylation of Akt in the aorta

To assess whether the hyperinsulinaemic state activates the PI3K pathway in vivo, the level of phosphorylation of Akt in the aorta was analysed by western blotting analysis with p-Akt (Ser-473) antibody. The aortas from the fructose-fed rats showed a higher level of phosphorylation of Akt compared with those from the control-fed rats (Fig. 4a,b). Densitometry indicated that the level of Akt phosphorylation in the aortas from fructose-fed rats was increased by 2.7-fold ( $p<0.01, n=4$ rats in each group) in the fasting state and 1.8fold ( $p<0.05, n=4$ rats in each group) in the postprandial state as compared with that in control-fed rats, respectively.

Table 1 Characteristics of the experimental groups

\begin{tabular}{|c|c|c|}
\hline & $\begin{array}{l}\text { Control diet-fed rats } \\
(\mathrm{n}=8)\end{array}$ & $\begin{array}{l}\text { Fructose diet-fed rats } \\
(\mathrm{n}=10)\end{array}$ \\
\hline Body weight (g) & $352.8 \pm 9.7$ & $343.2 \pm 7.3$ \\
\hline $\begin{array}{l}\text { Blood glucose } \\
(\mathrm{mmol} / \mathrm{l})\end{array}$ & $6.14 \pm 0.26$ & $6.17 \pm 0.20$ \\
\hline Insulin (pmol/1) & $330 \pm 52$ & $670 \pm 95^{\mathrm{a}}$ \\
\hline $\begin{array}{l}\text { Total cholesterol } \\
(\mathrm{mmol} / \mathrm{l})\end{array}$ & $1.34 \pm 0.08$ & $1.69 \pm 0.14^{\mathrm{b}}$ \\
\hline $\begin{array}{l}\text { Triacylglycerol } \\
(\mathrm{mmol} / \mathrm{l})\end{array}$ & $0.69 \pm 0.07$ & $1.90 \pm 0.34^{\mathrm{a}}$ \\
\hline CCL2 (pg/ml) & $50.0 \pm 5.9$ & $63.4 \pm 7.2$ \\
\hline
\end{tabular}

Values are mean \pm SEM. ${ }^{\mathrm{a}} p<0.01$ vs control rats; ${ }^{\mathrm{b}} p<0.05$ vs control rats a
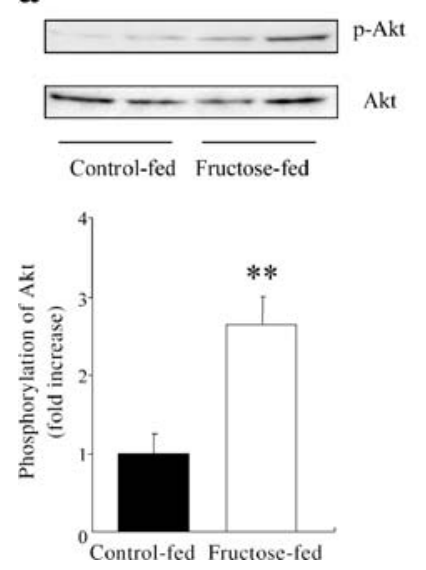
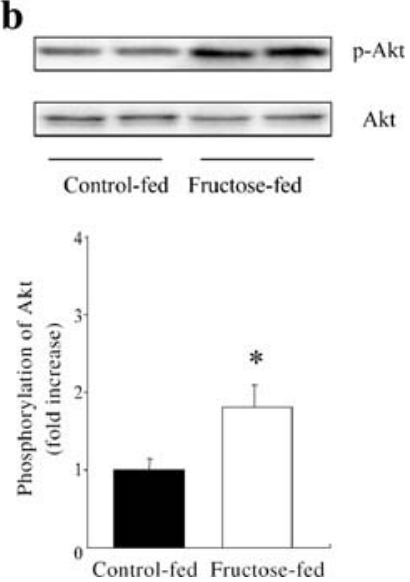

Fig. 4 Phosphorylation of Akt in the aorta. Western blot analysis was performed using aortas from experimental animals. Phosphorylation of Akt in the aorta from experimental animals in the fasting state (a) and the postprandial state (b). Results are expressed as means \pm SEM. ${ }^{* *} p<0.01$ vs control-fed rats, $n=4$ rats in each group, ${ }^{*} p<0.05$ vs control-fed rats, $n=4$ rats in each group

Aortic mRNA expression and protein production

We further examined the expression of $C c l 2, C e b p b$ and Cebpd mRNAs and production of the corresponding proteins in the aortas from rats in the two groups. Levels of Ccl 2 mRNA were significantly elevated by three-fold in the aortas of the fructose-fed rats compared with those of the control-fed rats (Fig. 5a). CCL2 protein was detected in the aortas of fructose-fed rats but not in those of control-fed rats (Fig. 5b). As demonstrated in Fig. 6a and b, Cebpb mRNA expression and C/EBP- $\beta$ production in the aortas from fructose-fed rats were significantly increased, by 3.3fold $(p<0.05)$ and by 1.6 -fold $(p<0.01)$, respectively,

$\mathbf{a}$
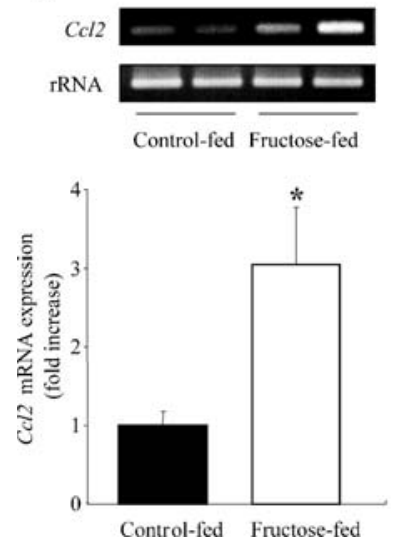

b
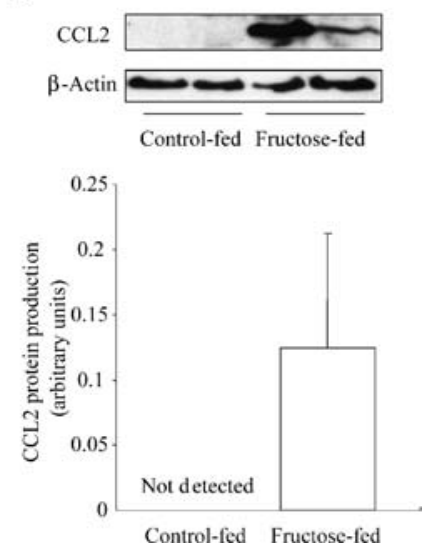

Fig. 5 Ccl2 mRNA expression examined by RT-PCR (a) and CCL2 production examined by western blot analysis (b) in the aorta. Results are expressed as means \pm SEM. ${ }^{*} p<0.05$ vs control-fed rats. Controlfed rats, $n=8$ (RT-PCR) and $n=5$ (western blot); fructose-fed rats, $n=10$ (RT-PCR) and $n=6$ (western blot) 
$\mathbf{a}$

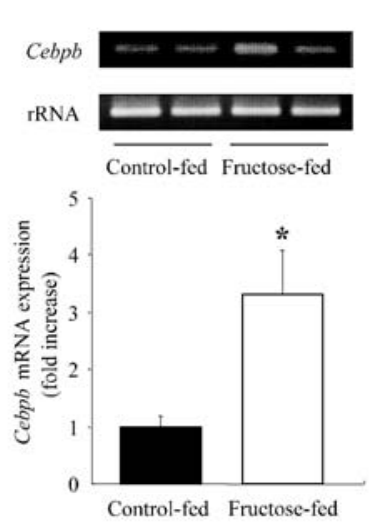

b

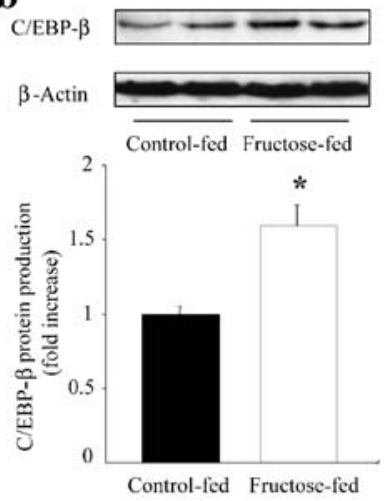

c
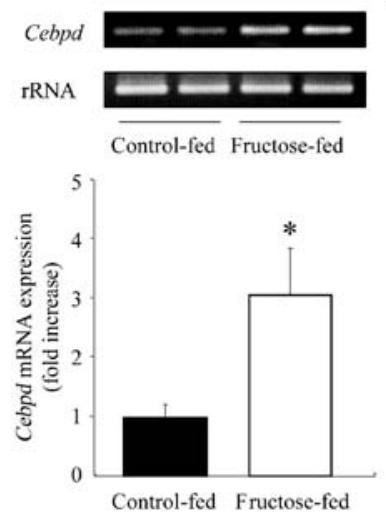

$\mathbf{a}$

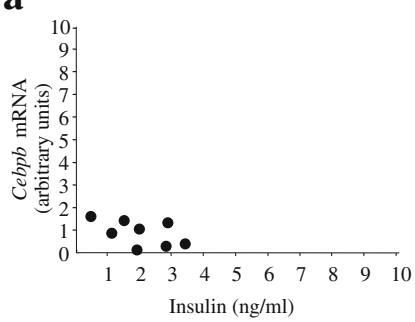

c

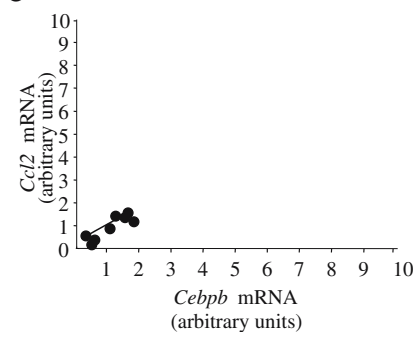

b

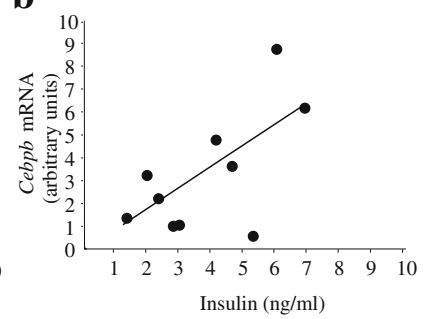

d

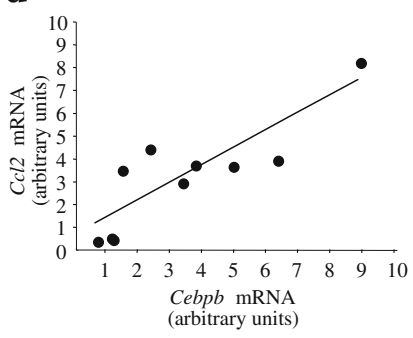

Fig. 7 Relationship between plasma insulin levels and expression of Cebpb, Cebpd and Ccl2 mRNAs in the aortas. a, b Correlation between plasma insulin levels of control (a) and fructose-fed (b) rats and aortic expression of Cebpb mRNA (control-fed rats, $r=0.53$ not significant, fructose-fed rats $r=0.647, p<0.05$ ). c, d Correlation between aortic expression of $C c l 2$ and $C e b p b$ mRNAs was observed in control (c) and fructose-fed (d) rats (control-fed rats, $r=0.87$, $p<0.01$, fructose-fed rats, $r=0.858, p<0.01$ ). Control-fed rats, $n=8$; fructose-fed rats, $n=10$

Binding of $\mathrm{C} / \mathrm{EBP}-\beta$ to the $5^{\prime}$ upstream region of the $\mathrm{Ccl} 2$ gene in the aortas from hyperinsulinaemic rats the aorta, as examined by RT-PCR and western blot analysis, respectively. a, b Levels of $C e b p b$ expression and C/EBP- $\beta$ production in the aortas. $\mathbf{c}, \mathbf{d}$ Levels of Cebpd expression and C/EBP- $\delta$ production in the aortas. Results are expressed as means \pm SEM. ${ }^{*} p<0.05$ vs controlfed rats. Control-fed rats, $n=8$ (RT-PCR) and $n=5$ (western blot); fructose-fed rats, $n=10$ (RT-PCR) and $n=6$ (western blot)

compared with those of control-fed rats. Cebpd mRNA expression and $\mathrm{C} / \mathrm{EBP}-\delta$ production in the aortas from fructose-fed rats were significantly increased, by 3.0 -fold $(p<0.05)$ and by 1.7 -fold $(p<0.01)$, respectively, compared with those of control-fed rats (Fig. 6c and d). Furthermore, immunohistochemical analysis of the aortas from either control-fed rats or fructose-fed rats showed that both CCL2 and C/EBP- $\beta$ were produced in smooth muscle cells (ESM Fig. 1a-d).

As shown in Fig. 7a and b, in fructose fed rats, plasma insulin levels were positively correlated with aortic Cebph mRNA levels $(r=0.65, p<0.05)$ and tended to correlate with aortic Cebpd mRNA levels ( $r=0.63, p=0.052$ ); no correlations were observed for the control-fed rats. Furthermore, in the aortas, strong positive correlations were observed between $C c l 2$ and $C e b p b$ mRNA levels (control-fed rats $r=0.87$, $p<0.01$, Fig. 7 c; fructose-fed rats $r=0.858, p<0.01$, Fig. 7 d) and between $C c l 2$ and Cebpd mRNA levels (control-fed rats $r=0.824, p<0.05$; fructose-fed rats $r=0.769, p<0.01$ ).

C/EBP- $\beta$ binding to the $5^{\prime}$ upstream region of the $C c l 2$ gene in aortas from rats in the two groups was examined with the ChIP assay using C/EBP- $\beta$ antibody. The amount of C/EBP- $\beta$ binding to the $5^{\prime}$ upstream region of the $\mathrm{Ccl} 2$ promoter in the aortas from fructose-fed rats was significantly increased by $430 \%(p<0.05)$ compared with that in control-fed rats (Fig. 8a and b).

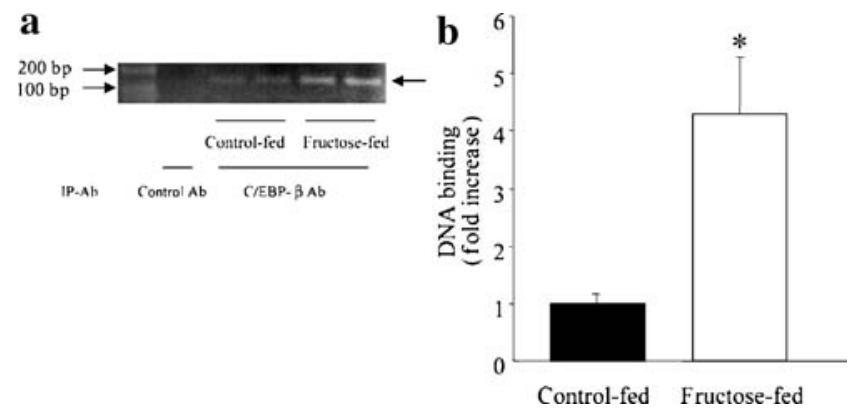

Fig. 8 Binding of C/EBP- $\beta$ to the $5^{\prime}$ upstream region of $C c l 2$ in the aortas from experimental animals. a, b The ChIP assay was carried out using $\mathrm{C} / \mathrm{EBP}-\beta$ antibody $(\mathrm{Ab})$. The amount of input DNA was quantified with Hoechst 33258 dye, and the quality was analysed with real-time PCR. The binding level of $\mathrm{C} / \mathrm{EBP}-\beta$ in the aorta from fructose-fed rats was higher than that of control rats. Values are mean \pm SEM. ${ }^{*} p<0.05$ vs control rats; $n=6$ in each group. IP, immunoprecipitation 
Expression of $C c l 2, C e b p b$ and Cebpd in the heart

We examined the expression of Ccl2, Cebpb and Cebpd mRNAs in hearts from rats in the groups (Fig. 9a). Consistent with the results for the aortas, the expression of $\mathrm{Ccl}$, Cebpb and Cebpd mRNAs in the hearts from the fructosefed rats was increased by 1.47-fold (Fig. 9b, $p<0.05, n=6$ rats in each group), 1.44-fold (Fig. 9c, $p<0.05, n=6$ rats in each group) and 1.57-fold (Fig. 9d, $p<0.05, n=6$ rats in each group), respectively, compared with expression levels in the control-fed rats.

\section{Discussion}

In the present study we found that the expression of Cebpb and Cebpd was increased in the aortas from fructose dietinduced hyperinsulinaemic rats. C/EBP family members, especially $\mathrm{C} / \mathrm{EBP}-\beta$ and $\mathrm{C} / \mathrm{EBP}-\delta$, are known to play an important role in the regulation of the expression of proinflammatory genes, including CCL2 $[8,23]$. We found that, in aortas, the levels of Cebpb and Cebpd mRNAs correlated very closely with the levels of $C c l 2$ mRNA. The ChIP assay demonstrated increased binding of C/EBP- $\beta$ to the C/EBP response element located at -3123 to $-3099 \mathrm{bp}$ from the starting point of rat $\mathrm{Ccl} 2$ transcription in the aortas from hyperinsulinaemic rats. In addition, inhibition of Cebpb gene expression with siRNA completely blocked the insulin-induced expression of $\mathrm{Ccl} 2$ in VSMCs. These findings clearly indicate that the increased expression of
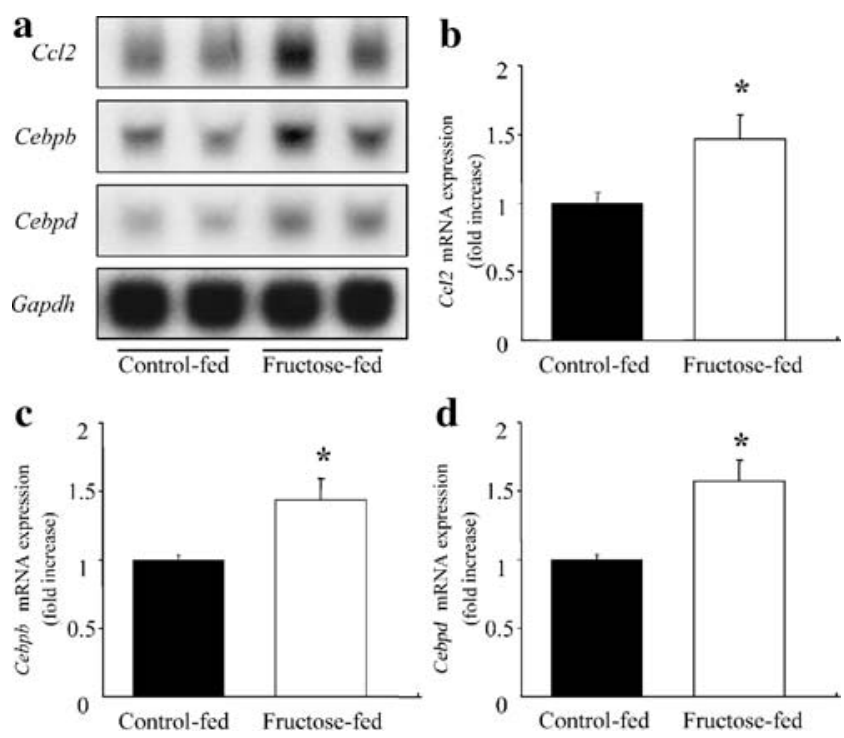

Fig. 9 The expression of $C c l 2, C e b p b$, and Cebpd mRNAs in hearts from experimental animals. a Levels of $C c l 2, C e b p b$ and $C e b p d$ mRNAs were examined by northern blot analysis. Representative results are shown. b-d Levels of Ccl2 (b) Cebpb (c) and Cebpd (d) in the hearts. Results are expressed as means \pm SEM. $* p<0.05$ vs control rats; $n=6$ in each group
Cebpb and Cebpd mRNAs in the aorta is responsible for the enhanced expression of $\mathrm{Ccl} 2$ in the aortas from hyperinsulinaemic rats. Importantly, CCL2 is reported to be play a role in most of the processes involved in the formation of atherosclerotic lesions [24] and is strongly expressed in human atheromatous lesions but not in normal arteries [25]. Furthermore, the selective knockout of CCR2, the receptor for CCL2, prevents the initiation of the atherosclerotic process in vivo [26]. Therefore, our present findings suggest a significant role for C/EBPs as regulators of CCL2 production in the development of atherosclerosis. However, our results do not necessarily imply that the induction of $\mathrm{Ccl} 2$ gene expression observed in the aorta in the hyperinsulinaemic state is exclusively due to an enhanced activity of C/EBPs. It has been reported that several transcription factors, including nuclear factor- $\mathrm{kB}$, have a role in the regulation of $\mathrm{Ccl} 2$ expression [27, 28]. Using an electrophoretic gel retardation assay, we have previously shown increased binding activity of NF- $\mathrm{KB}$ in the aorta and in the heart of fructose-feeding-induced hyperinsulinaemic rats using an electrophoretic gel retardation assay [21]. In addition to the effect on $\mathrm{Ccl} 2$ gene, $\mathrm{C} / \mathrm{EBP}-\beta$, and $\mathrm{C} / \mathrm{EBP}-\delta$ regulate the transcription of a number of genes involved in the inflammatory response $[8$, 29]. Furthermore, other reports have revealed a role for C/EBPs in the development of atherosclerosis [11-13]. Thus, increased expression of Cebpb and Cebpd in aortas from hyperinsulinaemic rats may be a significant factor to induce vascular inflammation leading to atherosclerosis.

Consistent with the results of a previous study [7], insulin increased levels of $\mathrm{C} / \mathrm{EBP}-\beta$, and $\mathrm{C} / \mathrm{EBP}-\delta$ in cultured VSMCs in a PI3K/Akt-dependent manner. In the hyperinsulinaemic rats, Cebpb mRNA expression in the aortas was strongly correlated with plasma insulin levels. Furthermore, the level of phosphorylation of Akt, a downstream molecule in the PI3K pathway, in the aortas were increased in the fructose-fed hyperinsulinaemic rats, suggesting chronic activation of PI3K in the aortas of these rats. These observations suggest that insulin stimulates the expression of Cebpb and Cebpd genes in a PI3K/Aktdependent manner in the aortas, as well as in cultured VSMCs. On the other hand, we were not able to rule out the possibility that some unknown factors related to the hyperinsulinaemic state caused the activation of the PI3K pathway observed in the present study. Instead of the activation of PI3K, Jiang et al. showed the activation of the Ras/mitogen-activated protein kinase (MAPK) pathway in response to insulin in the vascular tissues of genetically hyperinsulinaemic Zucker fatty rats [30]. In addition, it has been reported that insulin promotes numerous deleterious vascular effects by stimulating the actions of various growth factors acting through the MAPK signaling pathway [31]. Therefore, further investigation is needed to clarify the 
expression of $\mathrm{Ccl} 2$ through the MAPK pathway in the insulin-resistant state.

In conclusion, the expression of $\mathrm{Ccl} 2$, one of the proinflammatory cytokines, is stimulated by enhanced expression of C/EBP genes in the aorta of the insulinresistant rat. The overexpression of Cebpb and Cebpd in aortas of these rats is caused by chronic hyperinsulinaemia.

Acknowledgement This work supported by research grants-in-aid from the Ministry of Education, Science, Sports, and Culture of Japan.

\section{References}

1. Ross R (1999) Atherosclerosis - an inflammatory disease. N Engl J Med 340:115-126

2. Willerson JT, Ridker PM (2004) Inflammation as a cardiovascular risk factor. Circulation 109:II2-II10

3. Ruige JB, Assendelft WJ, Dekker JM, Kostense PJ, Heine RJ, Bouter LM (1998) Insulin and risk of cardiovascular disease: a meta-analysis. Circulation 97:996-1001

4. Shinozaki K, Hattori Y, Suzuki M et al (1997) Insulin resistance as an independent risk factor for carotid artery wall intima media thickening in vasospastic angina. Arterioscler Thromb Vasc Biol 17:3302-3310

5. Despres JP, Lamarche B, Mauriege P et al (1996) Hyperinsulinemia as an independent risk factor for ischemic heart disease. N Engl J Med 334:952-957

6. UK Prospective Diabetes Study (UKPDS) Group (1998) Intensive blood-glucose control with sulphonylureas or insulin compared with conventional treatment and risk of complications in patients with type 2 diabetes (UKPDS 33). Lancet 352:837-853

7. Sekine O, Nishio Y, Egawa K, Nakamura T, Maegawa H, Kashiwagi A (2002) Insulin activates CCAAT/enhancer binding proteins and proinflammatory gene expression through the phosphatidylinositol 3-kinase pathway in vascular smooth muscle cells. J Biol Chem 277:36631-36639

8. Poli V (1998) The role of C/EBP isoforms in the control of inflammatory and native immunity functions. J Biol Chem 273:29279-29282

9. Agrawal A, Cha-Molstad H, Samols D, Kushner I (2001) Transactivation of C-reactive protein by IL-6 requires synergistic interaction of CCAAT/enhancer binding protein beta (C/EBP beta) and Rel p50. J Immunol 166:2378-2384

10. Kleemann R, Gervois PP, Verschuren L, Staels B, Princen HM, Kooistra T (2003) Fibrates down-regulate IL-1-stimulated C-reactive protein gene expression in hepatocytes by reducing nuclear $\mathrm{p} 50$ NFkappa B-C/EBP-beta complex formation. Blood 101:545-551

11. Kelkenberg U, Wagner AH, Sarhaddar J, Hecker M, von der Leyen HE (2002) CCAAT/enhancer-binding protein decoy oligodeoxynucleotide inhibition of macrophage-rich vascular lesion formation in hypercholesterolemic rabbits. Arterioscler Thromb Vasc Biol 22:949-954

12. Yang ZH, Kitami Y, Takata Y, Okura T, Hiwada K (2001) Targeted overexpression of CCAAT/enhancer-binding protein-delta evokes enhanced gene transcription of platelet-derived growth factor alphareceptor in vascular smooth muscle cells. Circ Res 89:503-508

13. Takata Y, Kitami Y, Yang ZH, Nakamura M, Okura T, Hiwada K (2002) Vascular inflammation is negatively autoregulated by interaction between CCAAT/enhancer-binding protein-delta and peroxisome proliferator-activated receptor-gamma. Circ Res 91:427-433

14. Festa A, D'Agostino R Jr, Howard G, Mykkanen L, Tracy RP, Haffner SM (2000) Chronic subclinical inflammation as part of the insulin resistance syndrome: the Insulin Resistance Atherosclerosis Study (IRAS). Circulation 102:42-47

15. Wu T, Dorn JP, Donahue RP, Sempos CT, Trevisan M (2002) Associations of serum C-reactive protein with fasting insulin, glucose, and glycosylated hemoglobin: the Third National Health and Nutrition Examination Survey, 1988-1994. Am J Epidemiol $155: 65-71$

16. Obata T, Kashiwagi A, Maegawa $H$ et al (1996) Insulin signaling and its regulation of system A amino acid uptake in cultured rat vascular smooth muscle cells. Circ Res 79:1167-1176

17. Duong DT, Waltner-Law ME, Sears R, Sealy L, Granner DK (2002) Insulin inhibits hepatocellular glucose production by utilizing liver-enriched transcriptional inhibitory protein to disrupt the association of CREB-binding protein and RNA polymerase II with the phosphoenolpyruvate carboxykinase gene promoter. J Biol Chem 277:32234-32242

18. Shao J, Qiao L, Janssen RC, Pagliassotti M, Friedman JE (2005) Chronic hyperglycemia enhances PEPCK gene expression and hepatocellular glucose production via elevated liver activating protein/liver inhibitory protein ratio. Diabetes 54:976-984

19. Yamada S, Kojima H, Fujimiya M, Nakamura T, Kashiwagi A, Kikkawa R (2001) Differentiation of immature enterocytes into enteroendocrine cells by Pdx1 overexpression. Am J Physiol Gastrointest Liver Physiol 281:G229-G236

20. Nakamura T, Kishi A, Nishio $Y$ et al (2001) Insulin production in a neuroectodermal tumor that expresses islet factor-1, but not pancreatic-duodenal homeobox 1. J Clin Endocrinol Metab 86:1795-1800

21. Shinozaki K, Nishio Y, Okamura T et al (2000) Oral administration of tetrahydrobiopterin prevents endothelial dysfunction and vascular oxidative stress in the aortas of insulin-resistant rats. Circ Res 87:566-573

22. Nagai Y, Nishio Y, Nakamura T, Maegawa H, Kikkawa R, Kashiwagi A (2002) Amelioration of high fructose-induced metabolic derangements by activation of PPARalpha. Am J Physiol Endocrinol Metab 282:E1180-E1190

23. Merola M, Blanchard B, Tovey MG (1996) The kappa B enhancer of the human interleukin- 6 promoter is necessary and sufficient to confer an IL-1 beta and TNF-alpha response in transfected human cell lines: requirement for members of the C/EBP family for activity. J Interferon Cytokine Res 16:783-798

24. Shin WS, Szuba A, Rockson SG (2002) The role of chemokines in human cardiovascular pathology: enhanced biological insights. Atherosclerosis 160:91-102

25. Takeya M, Yoshimura T, Leonard EJ, Takahashi K (1993) Detection of monocyte chemoattractant protein-1 in human atherosclerotic lesions by an anti-monocyte chemoattractant protein-1 monoclonal antibody. Hum Pathol 24:534-539

26. Boring L, Gosling J, Cleary M, Charo IF (1998) Decreased lesion formation in CCR2-/- mice reveals a role for chemokines in the initiation of atherosclerosis. Nature 394:894-897

27. Ueda A, Ishigatsubo Y, Okubo T, Yoshimura T (1997) Transcriptional regulation of the human monocyte chemoattractant protein1 gene. Cooperation of two NF-kappaB sites and NF-kappaB/Rel subunit specificity. J Biol Chem 272:31092-31099

28. Wang Y, Rangan GK, Goodwin B, Tay YC, Harris DC (2000) Lipopolysaccharide-induced MCP-1 gene expression in rat tubular epithelial cells is nuclear factor-kappaB dependent. Kidney Int 57:2011-2022

29. Ramji DP, Foka P (2002) CCAAT/enhancer-binding proteins: structure, function and regulation. Biochem J 365:561-575

30. Jiang ZY, Lin YW, Clemont A et al (1999) Characterization of selective resistance to insulin signaling in the vasculature of obese Zucker (fa/fa) rats. J Clin Invest 104:447-457

31. Hsueh WA, Law RE (1999) Insulin signaling in the arterial wall. Am J Cardiol 84:21J-24J 